DOI http://dx.doi.org/10.18551/rjoas.2016-09.04

\title{
UTILIZATION PATTERN OF VITEX DONANIA IN UROMI, ESAN NORTH-EAST LOCAL GOVERNMENT AREA OF EDO STATE, NIGERIA
}

\author{
Opute O.H., Idumah F.O., Olugbire O.O., Arabomen O. \\ Forestry Research Institute of Nigeria, Ibadan, Nigeria \\ E-mail: oarabomen14@gmail.com
}

\begin{abstract}
The utilization pattern of Vitex doniana a non-timber forest product (NTFP) was examined in Uromi, Esan North East Local Government Area of Edo State, Nigeria. Data was collected from one hundred (100) respondents in households using interview and questionnaire survey. Descriptive statistics, t-test and Pearson chi-square were used to analyse data collected. The result showed that V. doniana is well known as an important NTFP in the area since majority of the respondents $(97.8 \%)$ are aware of the tree species as a result of the high rate of consumption (88.6\%). It was observed that some respondents $(77.8 \%)$ do not consume it because of their ignorance about it, while few $(22.2 \%)$ was because of the color. The result also shows that, $(48.8 \%)$ of the respondents consume it as food while $16.3 \%$ and $35 \%$ consume it for the purpose of ethno medicine and food combined with ethno medicine respectively. This result also reveals that fruit is the major part consumed for food $(89.4 \%)$ and ethno medicine (46.3\%). It is a widely accepted fruit tree species in the study area, based on the fact that about $95.6 \%$ agreed that it is widely accepted and its consumption trend is on the increase (88.3\%) which shows that the people like it. On the other hand, many people $(37.5 \%)$ cannot access it due to its threatened conservation status as it is no longer cultivated in the forest as before as well as its lack of NAFDAC number. However, the result of the chi-square shows that there is no significant difference $(p>0.05)$ in the consumption of this species among the various primary occupation categories and also, that the consumption rate does not significantly $(p>0.05)$ depend on the educational status. Chisquare also shows that, there is no significant $(p>0.05)$ difference in their consumption. Consumption of $V$. doniana significantly $(p<0.05)$ depends on household size and consumption does not depend significantly $(p>0.05)$ on the economic status. Therefore appropriate recommendations capable for the sustainability of the species were given.
\end{abstract}

\section{KEY WORDS}

Vitex doniana, utilisation, pattern, household.

Forest provides a variety of timber and non-timber forest products (NTFPs) that include products such as firewood, medicinal plants, flowers, fruits, leaves and roots. These contribute to household especially those living in the rural areas and it is commonly viewed as greatest for those living in or adjacent to forests (Wollenberg and Ingles 1998; Colchester 2008). Forest foods also provides people with the opportunity to bridge the gap between food shortage and next crop harvest and they play an important role in the global system, in case of disaster resulting from floods, droughts, famines and war (FAO, 2006).

The importance on NTFPs has increased in recent times, as some studies revealed that its use contributes to rural livelihood development (Saxena, 2003) and that its harvesting could be less ecologically destructive than timber extraction (FSC, 2002; Myers, 1988). The interest in production and utilization of NTFPs is increasing rapidly and numerous efforts are in place towards increasing awareness on the value and uses of these products, their management and market potentials (Ferris et al; 2001).

Vitex doniana is a NTFP, which belongs to the family verbenaceae and the vitex genus. It can actually be found all over Africa's tropical regions. It flowers from August to November and fruits from January to April. It is commonly called "dinya» in Hausa, "Galbihi» in Fula, "Ucha-Koro» in Igbo, "Oori-nla» in Yoruba and "Oriri» in Edo. The fruit is a dark brown drupe with succulent pulp (Umar et al 2010). The matured fruits contain blackish pulp which 
is sweet and edible and it is eaten fresh. This pulp also serves in jam preparation. A beverage is made from the fruit juice, whereas boiled fruits are the basis for an alcoholic liquor and wine $(\mathrm{Ky}, 2008)$. It is an important indigenous fruit or leafy vegetable in Africa (Burkill, 2000; Maundu et al 2009). In traditional medicines it has several applications (Egbekun et al., 1996) such as for the treatment of anaemia and the root is used for gonorrhea (FAO, 1983). It is also supposed to improve fertility and is used to treat jaundice, leprosy and dysentery (Don Maydell, 1986). The inner bark has many uses as a treatment for malaria, colds chest pains, coughs, diarrhea, muscle pains, stomach aches and general body pains (Rulan Garanga, 1989). It is known to have socio-economic potentialities due to its food, therapeutic and cultural uses (Oumorou et al; 2010). Despite the socio-economic importance of this tree, it is going into extinction due to its high utilization pressure combined with the low regeneration ability which cause a steady depletion of natural populations and no clear and straight forward conservation strategies have been developed neither at the community level or at national level apart from the fact that the species might be protected in natural reserves where it occurs (Oumoroju, et al 2010; N' Dani kou, et al 2011). At the community level, although people are aware of the threat on Vitex doniana but there is limited conservation actions taken to sustain the utilization of the species. Conservation actions usually referred to include the sparing of the tree during land clearing (Oumorou, et al 2010; N' Daniku et al 2011; Vodouhi et al 2011).

Though Vitex doniana, has numerous utilizations with promising economic potential for poverty alleviation in rural and peri-urban areas in Africa (Achighan et al., 2014), as its utilization could lead to food security for the area along with health benefits this brings to the population. In traditional medicines it has several applications (Egbekun et al., 1996). This study therefore assessed the consumption pattern of Vitex doniana across households in the study area area with the aim of making recommendations for its conservation in the area.

\section{METHODOLOGY OF RESEARCH}

Study Area. Uromi is in Esan-North East Local Government Area (LGA) of Edo State, Nigeria. It lies in North-Eastern Esan in the State, located on longitude $3^{0} 24^{\prime}$ and latitude $6^{0} 27$ North. Estimated population of Uromi is about 119,346 (NPC, 2006).

Climate. There are two rainy seasons with the heaviest rain falling from April to July and a weather rainy season in October and November. There is a brief relatively dry spell in August and September and a longer dry season from December to March.

Sampling procedure and sample size. Four (4) major communities were randomly selected for the study and deemed to be sufficient representatives of the study area in terms of the utilization of Vitex doniana. Twenty five (25) respondents were randomly selected from each of the selected communities making a total of one hundred (100) respondents to be interviewed for the study. Data were obtained through the use of questionnaires containing open and closed ended questions to obtain information based on intended objectives and were administered to the household/consumers in the study area.

Data analysis. Data collected from the study were subjected to simple descriptive statistics and was also used to analyse, present the socio-economic characteristics, utilization modes of the respondents in the study area. The students t-test was used to compare the different uses of Vitex doniana in the study area by the consumers/households while chi-square was used to determine the factors affecting the utilization pattern.

\section{RESULTS AND DISCUSSION}

Consumption, Sources and Acceptability of Vitex doniana. The result (Table 1) shows that $\mathrm{V}$. doniana is no more a new important tree species in the study area. It can be observed that $97.8 \%$ of the respondents are aware of the tree species. The popularity of this tree species may have resulted to its high rate of consumption (88.6\%) in households. However, out of the few respondents that has not been consuming it hitherto $(11.4 \%)$, high proportion $(77.8 \%)$ replied that their failure to consume it was of their ignorance about the species, while 
few $(22.2 \%)$ mentioned that it was the color that made them not to have been consuming it. The result further revealed that $48.8 \%$ of the respondents consume $\mathrm{V}$. doniana for the purpose of food while $16.3 \%$ and $35 \%$ consume it for ethno-medicine and food combined with ethno medicine respectively. The fruit of $\mathrm{V}$. doniana is the major part consumed for food $(89.4 \%)$ and ethno-medicine $(46.3 \%)$. Majority of the respondents $(70.5 \%)$ emphasized that they source the consumed part of the species from market. Other sources of the species are forest $(11.4 \%)$ and farmland $(11.2 \%)$. V. doniana is a widely accepted fruit tree species in the study location since $95.6 \%$ agreed that it is widely accepted. The result also showed that the consumption trend of the tree species is on the increase $(88.3 \%)$ and has been linked to the fact that people like it $(2.7 \%)$, it is good for health $(42.7 \%)$, it has high ethno-medicinal importance $(28 \%)$, many people use it $(20 \%)$ and it is sweet $(6.7 \%)$. On the other hand, people $(37.5 \%)$ have not been able to have access to it as a result of its threatened conservation status, it is no longer cultivated in the forest as before $(12.5 \%)$ as well as its lack of NAFDAC number (50\%).

Table 1 - Consumption, Sources and Acceptability of Vitex doniana

\begin{tabular}{|c|c|c|}
\hline $\mathrm{n} / \mathrm{n}$ & Variable & Percentage $\%$ \\
\hline Awareness & $\begin{array}{l}\text { Yes } \\
\text { No }\end{array}$ & $\begin{array}{c}97.8 \\
2.2 \\
\text { Total } 100\end{array}$ \\
\hline Consumption & $\begin{array}{l}\text { Yes } \\
\text { No }\end{array}$ & $\begin{array}{c}88.6 \\
11.4 \\
\text { Total } 100\end{array}$ \\
\hline Reason for not consuming & $\begin{array}{c}\text { Lack of awareness } \\
\text { Color }\end{array}$ & $\begin{array}{c}77.8 \\
22.2 \\
\text { Total } 100\end{array}$ \\
\hline Purpose/Use & $\begin{array}{c}\text { Food } \\
\text { Ethno-medicine } \\
\text { Both }\end{array}$ & $\begin{array}{c}48.8 \\
16.3 \\
35.0 \\
\text { Total } 100\end{array}$ \\
\hline Part Used for food & $\begin{array}{l}\text { Leaf } \\
\text { Fruit } \\
\text { Bark }\end{array}$ & $\begin{array}{c}8.2 \\
89.4 \\
2.4 \\
\text { Total } 100\end{array}$ \\
\hline Part used for ethno-medicine & $\begin{array}{c}\text { Leaf } \\
\text { Fruit } \\
\text { Bark } \\
\text { All }\end{array}$ & $\begin{array}{c}20.4 \\
46.3 \\
11.1 \\
22.2 \\
\text { Total } 100 \\
\end{array}$ \\
\hline Source & $\begin{array}{c}\text { Market } \\
\text { Forest } \\
\text { Farmland }\end{array}$ & $\begin{array}{c}62.0 \\
10.0 \\
16.0 \\
\text { Total } 88 \\
\end{array}$ \\
\hline Acceptability & $\begin{array}{l}\text { Yes } \\
\text { No }\end{array}$ & $\begin{array}{c}95.6 \\
4.4 \\
\text { Total } 100\end{array}$ \\
\hline Consumption trend in five years & $\begin{array}{l}\text { Increasing } \\
\text { Decreasing }\end{array}$ & $\begin{array}{c}88.3 \\
11.7 \\
\text { Total } 100\end{array}$ \\
\hline Reason for Increase & $\begin{array}{c}\text { Likeness for it } \\
\text { Ethno-medical importance } \\
\text { Used by many } \\
\text { It is sweet }\end{array}$ & $\begin{array}{c}2.7 \\
42.7 \\
28.0 \\
20.0 \\
6.7 \\
\text { Total } 100\end{array}$ \\
\hline Reason for Decrease & $\begin{array}{c}\text { Threatened } \\
\text { Not cultivated as before } \\
\text { Not approved by NAFDAC }\end{array}$ & $\begin{array}{c}37.5 \\
12.5 \\
50.0 \\
\text { Total } 100\end{array}$ \\
\hline
\end{tabular}

Effect of Socio-Economic Characteristics of Households on Consumption of Vitex doniana. In the study area, the sequence of consumption of $\mathrm{V}$. doniana showed that farmers 
self-employed, students and civil servants at $100 \%, 93.8 \%, 90 \%$ and $87 \%$ were the major consumers respectively (Fig 1). However, the chi-square statistics (Table 2) revealed that there is no significant difference in the consumption of this species among the various primary occupation categories at $p>0.05$. Based on the educational status (Fig 2), people with primary school leaving certificate has the same consumption rate $(100 \%)$ of $\mathrm{V}$. doniana with the respondents without formal education, but greater than those with secondary school certificate $(86.4 \%)$ and higher degree certificate $(86.5 \%)$. Hence, the consumption rate does not significantly depend on the educational status (Table 2 ).

Table 2 - Consumption of $\mathrm{V}$. doniana across socio-economic variables

\begin{tabular}{lccc}
\hline \multicolumn{1}{c}{ Variable } & Chi-square & Df & p-value \\
\hline Primary occupation & 1.49 & 3 & $0.683 \mathrm{~ns}$ \\
Educational status & 1.83 & 3 & $0.607 \mathrm{~ns}$ \\
Resident area & 1.27 & 1 & $0.259 \mathrm{~ns}$ \\
Age & 4.94 & 2 & $0.084 \mathrm{~ns}$ \\
Household size & 11.17 & 2 & $0.004^{*}$ \\
Economic status & 3.27 & 2 & $0.194 \mathrm{~ns}$ \\
\hline
\end{tabular}

$n s=$ not significant at $p=0.05$

${ }^{*}=$ significant at $p=0.05$

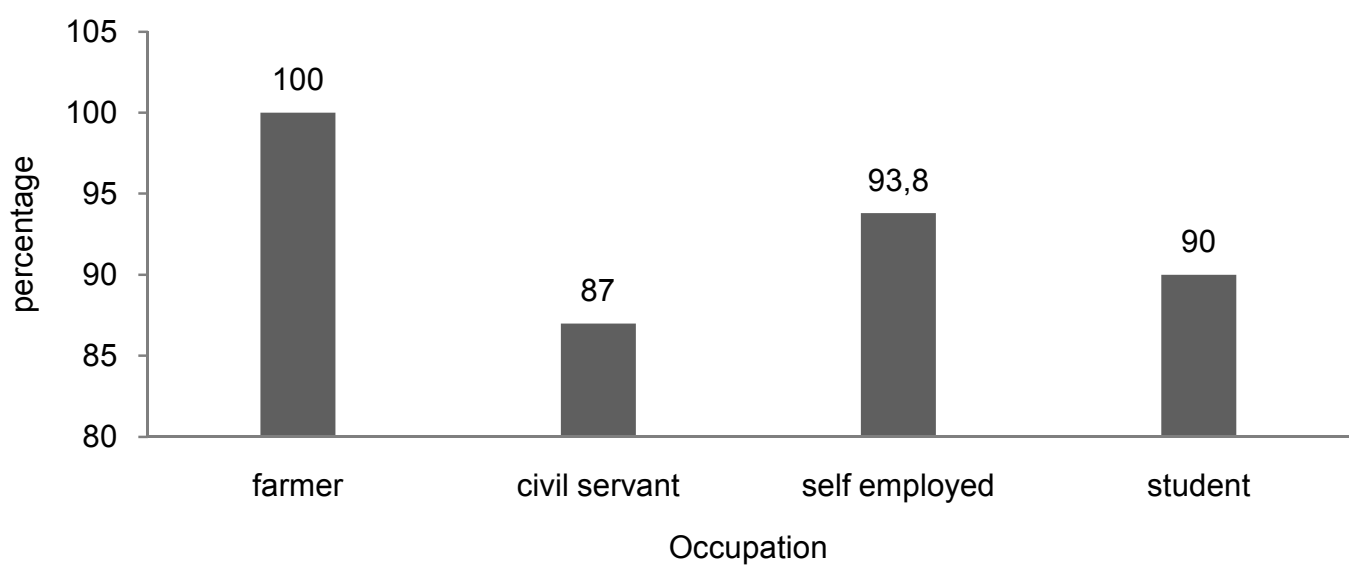

Figure 1 - Consumption of $\mathrm{V}$. doniana and occupation

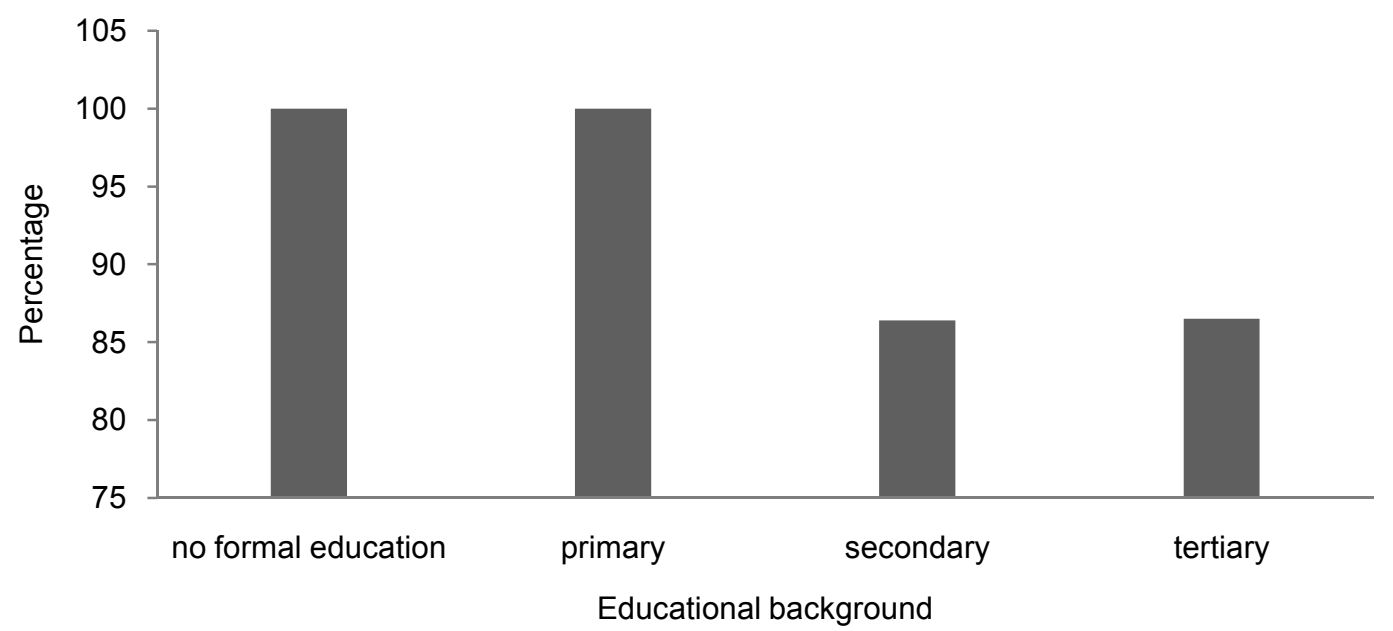

Figure 2 - Consumption of $\mathrm{V}$. doniana and education 
Figure 3 shows that people, who live in rural area consume V.donia more than those in urban area, although, chi-square shows that there is no significant difference in their consumption. Figure 4 shows that older respondents consume V. doniana than the younger ones. Figure 5 shows that $\mathrm{V}$. doniana consumption increases with increase in household size of the respondents.

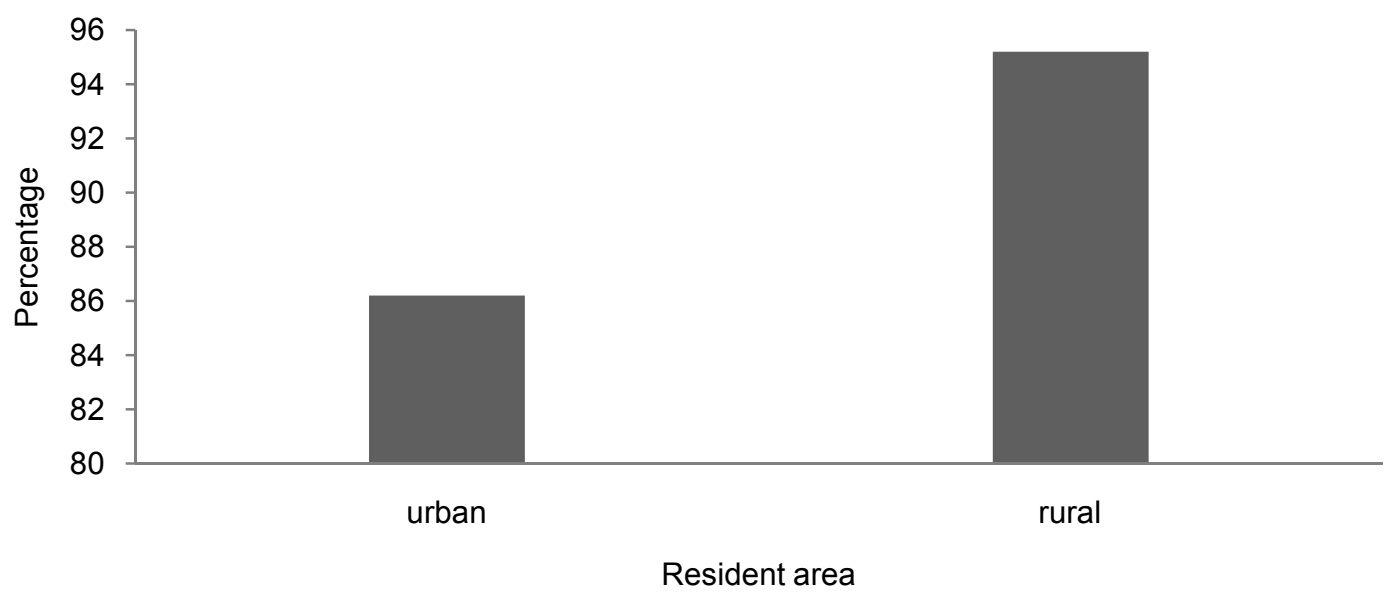

Figure 3 - Consumption of $\mathrm{V}$. doniana and residential area

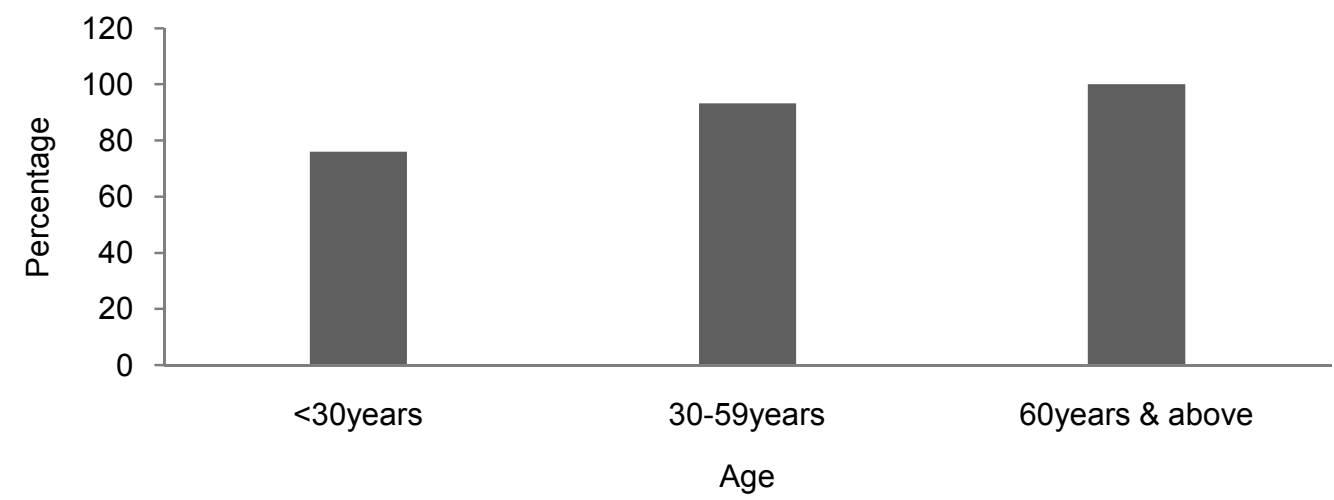

Figure 4 - Consumption of $\mathrm{V}$. doniana and age of the respondent

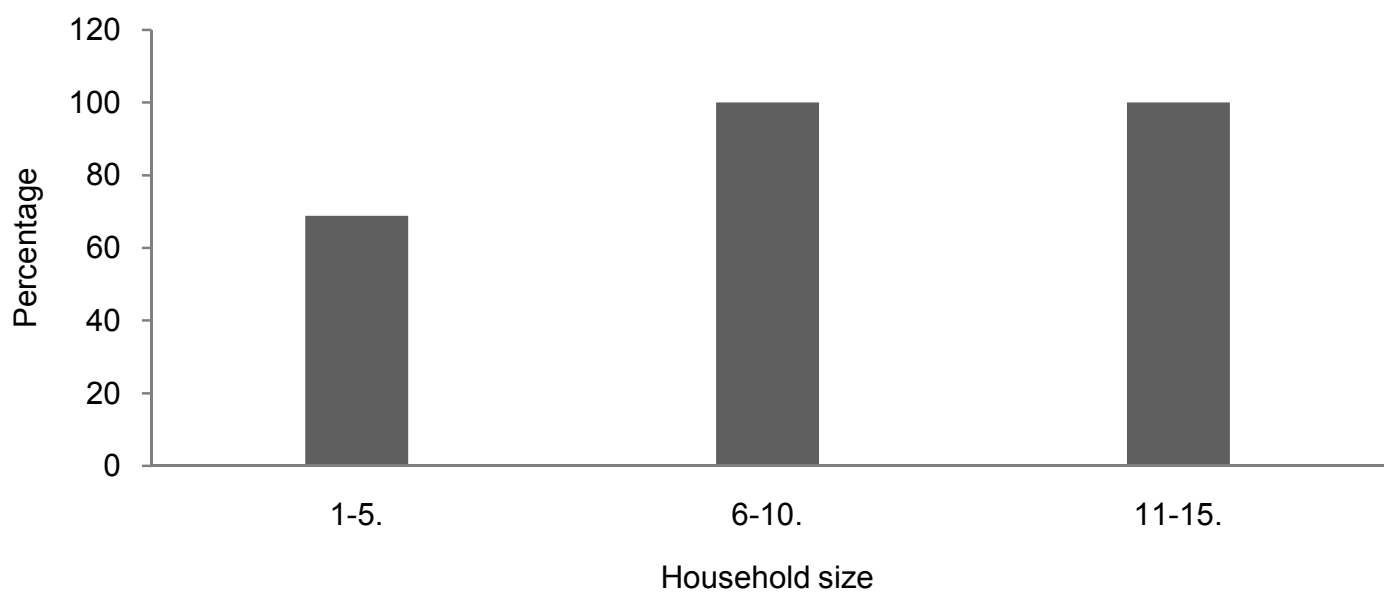

Figure 5 - Consumption of $\mathrm{V}$. doniana and household size of the respondent 


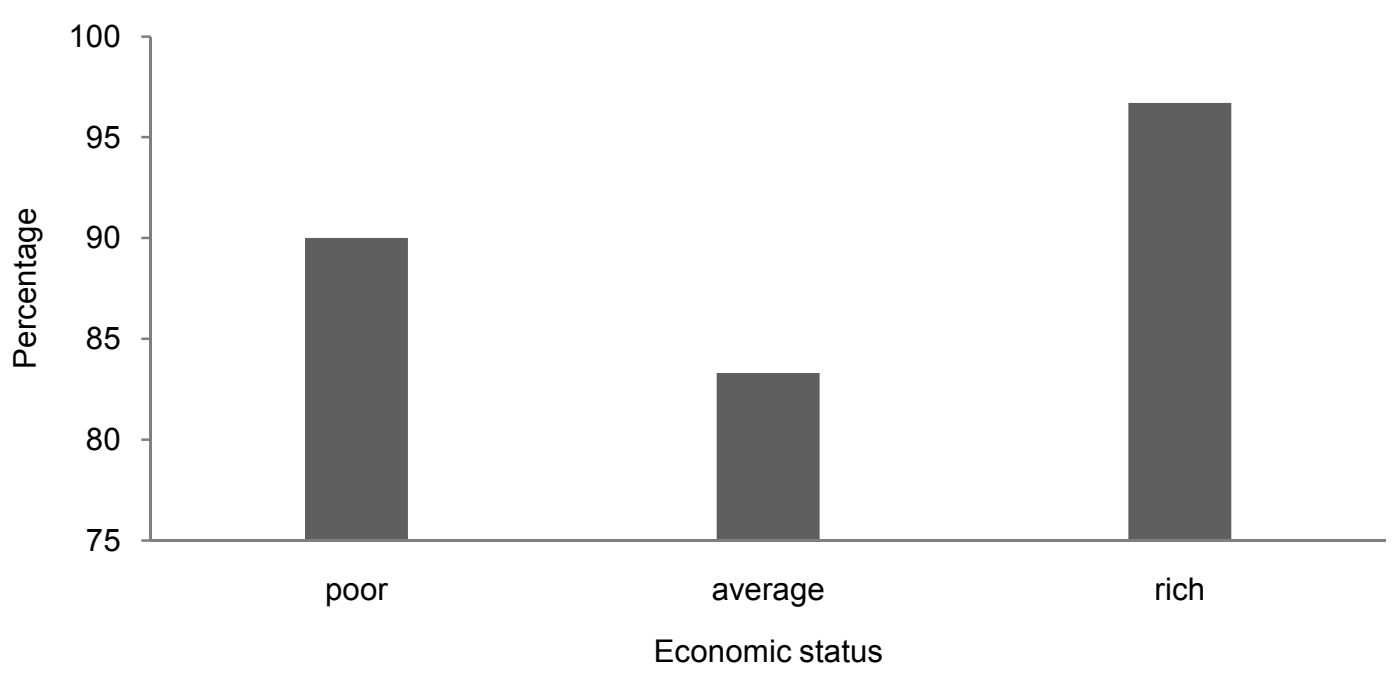

Figure 6 - Consumption of $\mathrm{V}$. doniana and economic status of the respondent

This is well confirmed by the chi-square result which shows that consumption of $V$. doniana significantly depend on household size (Table 2). In addition, rich people happened to consume $\mathrm{V}$. doniana more than the poor and average people (Figure 6 ) but consumption does not depend significantly on the economic status.

\section{CONCLUSION}

NTFPs are very important especially as it helps in both nutritional and ethn-omedicinal aspect to man. Vitex doniana is one of the important NTFPs that people utilize in the study area. This work has provided some information on different utilization pattern of Vitex doniana in the study area. Based on the findings of this study, it can be concluded that it is known by most of the respondents in the study area and some are not aware of the species as a result of their ignorance and its color. Though it is utilized for both nutritional and medicinal purposes. It is mainly used as sweetener mixed with other foods; this is in agreement with Burkill, (2010), who stated that, the syrup of vitex doniana can substitute for other syrup as nutritive sweetener. The species is threatened based on increasing rate of utilization. This study shows that $\mathrm{V}$. doniana is no more a new important tree species and its popularity in the study area, may have resulted to its high rate of consumption and this corroborates with the findings of Lins et al (2010) which stated that, the apparent uniform spread of knowledge would be explained by the fact that knowledge is passed on through generations with time and that the homogeneity is also associated with the fact that it is used by local people as food source and for its medicinal value.

\section{RECOMMENDATION}

From the result and conclusion of this study, it is therefore recommended that as a result of increasing rate of utilization, threatened conservation and ignorance about the species by some people, it is recommended that there is need to popularize the species among the people as a better knowledge of these species will help in its sustainability, appropriate domestication and regeneration of the species should be encouraged which should also be harvested and utilized sustainably. This will ensure availability of the species as well as in achieving sustainable management of the forest. There is need for sustainable utilization/ conservation of this species. Its sustainable use requires better knowledge of these populations and their various modes of regeneration. In this study, the utilization of V.doniana was investigated in the study area, to identify the degree of its use and rate of extinction and to identify the various uses by the people of the study area. 


\section{REFERENCES}

1. Achigan-Dako, E.G., Pasquini, M.W., Assogba, K.F., N'Danikou, S., Yedomonhan, H., Dansi, A and Ambrose-Oj, B (Eds), (2010). Traditional vegetables in Benin, Institute National des Recherches Agricoles du Benin, Imprimeries du CENAP, Cotonou.

2. Burkill, H.M. (2010). The useful plants of West Tropical Africa (second edition), 5, Families S 2, Kew, Richmond, United Kingdom.

3. Colchester, M. (2008). Beyond tenure. rights-based approaches to peoples and Forests. Some lessons from the forest people program. Rights and Resources Initiative, Washighton, DC.

4. Egbekun, M.K., Akowe, J.I and Ede, K.J (1996). Physio-chemical and sensory properties of formulated syrup from black plum (Vitex doniana) Fruit. Plant Foods for Human Nutrition, 49:301-306.

5. FAO. (1983). Food and fruit-bearing forest species- Examples from East Africa. Forestry paper 44(1):83.

6. Ferris, R.S.B., Collision, B., Wanda, K., Jagwe, J and Wright, P. (2001) . Evaluating the marketing opportunities for shea nuts and shea nut products in Uganda . Foodnet Report, USAID.

7. Forest Steward Council (FSC). Pacific Coast (USA) : Regional Forest Stewardship Standard: Version 7-9.

8. Global Forest Resources Assessment (2005). Progress towards sustainable Forest Management, FAO, Forestry Paper, 147.

9. Ky., K.J.M (2008). Vitex doniana sweet, In: Louppe, D., Otteng-Amoako, A.A and Brick, M. (eds.). Timbers/Bois d' Oeuvre 1. Backhuys Publishers, Leiden,/CTA,Wageningen, PROTA Foundation, Wageningen, Pays Bas. 7 (1):578-581.

10. Lins-Neto, E.M.F., Peroni, N and de'Albuqueroque, P.U (2010). Traditional knowledge and management of Umbu (Spondias tuberose, Anacardiaceae): an endemic species from the semi-arid region of North-Eastern Brazil. Economic Botany. 64(1):11-21.

11. Maundu, P., Achigan-Dako, E.G and Morimoto, Y (2009). Biodiversity of African vegetables, In: Shackeleton, C.M., Pasquin, M.W and Drescher, A.W. (eds). African indigenous vegetables. Urban Agriculture. 65-104.

12. Myers, N (1988). Tropical Forests: Much more than stocks of wood. Journal of Tropical Ecology. 4:209-221.

13. N'Danikou, S., Achigan-Dako, G.E and Wong, J.L.G (2011). Eliciting local values of wild edible plants in Southern Benin to identify priority species for conservation. Economic Botany 65:381-395.

14. Oumorou, M., Sinadouwirou, T., Kiki, M., Glele-Kaka, R, Munsah, G.A and Sinsin, B (2010). Disturbance and population structure of Vitex doniana sweet in Northern Benin, West Africa, International Journal of Biology and Chemical Sciences. 4:624-632.

15. Rulan-Garanga, Z.K. (1989). Some important indigenous medicinal and aromatic plants in the wild flora of Tanzania mainland. Tropical Forestry Working Paper. 24.

16. Saxena, N.C. (2003). Livelihood diversification and non-timber forest products in Orissa: wider lessons on the scope for policy change? Overseas Development Institute Working Paper. 223.

17. Vodouhie, S.R., Dansi, A., Avohou, H.T., Kpeki, B and Azihou, F. (2011).Plant domestication and its contributions to in-situ conservation of genetic resources in Benin. International Journal of Biodiversity Conservation. 3:40-56. 